\title{
INOVASI KURIKULUM DALAM PEMBELAJARAN BAHASA INGGRIS
}

\author{
Oleh Ana Fergina ${ }^{1}$
}

\begin{abstract}
Inovasi dalam pengembangan pembelajaran Bahasa Inggris sangat penting terutama pada kelas besar. Pada tulisan ini, akan dikembangkan inovasi dalam pembelajaran Bahasa Inggris di tingkat universitas. Inovasi pembelajaran ini membandingkan inovasi yang dipakai oleh Sarwar dan penulis sendiri pada konteks kelas yang kurang lebih sama, yaitu kelas besar.. Dari hasil analisa, diketahui bahwa keberhasilan pembelajaran dengan inovasi yang dipakai oleh Sarwar dan Penulis sendiri dapat berhasil jika ada kerja sama antara pengajar, mahasiswa dan unsur akademis lain.
\end{abstract}

\section{Pendahuluan}

Pendekatan komunikatif yang telah dikembangkan sejauh ini dalam pengajaran bahasa telah memberikan banyak perbaikan dalam inovasi Pengajaran Bahasa Inggris (English Language Teaching/ELT). Desain silabus yang telah dikembangkan untuk memenuhi pendekatan ini, misalnya silabus nosional / fungsional, pengajaran bahasa berbasis tugas, pendekatan alami, silabus berbasis proses dan silabus prosedural (Markee, 2001, hal 118). Menurut Markee (2001) tidak banyak spesialis kurikulum faham bagaimana dan mengapa inovasi berkembang. Hal ini karena pembuat kurikulum perlu mengevaluasi pelaksanaan inovasi dalam pengajaran bahasa (hal. 118)

Inovasi dalam ELT memberikan manfaat kepada pengajar sebagai pelaksana pertama di kelas khususnya di kelas yang jumlah mahasiswanya banyak (melebihi 30 orang). Pada umumnya pengajar sangat sulit untuk fokus pada mahasiswa dan materi ajar pada saat yang bersamaan di kelas besar. Oleh karena itu, dengan memiliki inovasi dalam pengajaran bahasa, diharapkan para pengajar dapat berkonsentrasi pada materi dan mahasiswa dan memberikan kesempatan kepada mahasiswa untuk mengekspresikan ideide mereka dengan teman-teman mereka.

${ }^{1}$ Ana Fergina adalah :pengelola UPT Bahasa Untan 
Berkenaan dengan konsep ini, tulisan ini akan membahas tentang inovasi dalam ELT. Pada bagian pertama akan diidentifikasi inovasi Sarwar dengan menggunakan kerangka kerja Markee. Pada bagian kedua, penulis akan mengidentifikasi inovasi yang digunakan penulis sendiri dengan menggunakan kerangka yang sama. Sedangkan pada bagian terakhir akan Penulis akan membandingkan inovasi Sarwar dengan inovasi penulis sendiri di ELT.

\section{Inovasi Sarwar}

Siapa (Who)

Dalam inovasi Sarwar (2001), dia telah memainkan empat peran pada saat yang sama yaitu sebagai pengadopsi (adopter), pelaksana (implementer), pemasok(supplier), dan agen perubahan (change agent). Menurut Markee (2001, hal 119), pengajar adalah pemain utama dalam mempromosikan inovasi dalam membuat silabus. Sarwar sebagai adopter pada saat dia menjadi orang yang memutuskan apakah inovasi akan diadopsi atau tidak. Dia sebagai implementer saat ia sendiri sebagai seorang pengajar dan menerapkan strategi di kelas sendiri. Kennedy (1988, seperti dikutip dalam Markee, 2001, hal 119) menyatakan bahwa "desainer kurikulum dan materi adalah supplier". Mengacu pada ini, Sarwar adalah orang yang merancang materi dan menjadi adopter pada saat yang bersamaan. Selanjutnya, Kennedy (1988, dikutip dalam Markee, 2001, hal 119) mendefinisikan change agent sebagai ahli kurikulum asing di suatu negara. Karena Sarwar adalah pakar kurikulum asing di Pakistan, ia dianggap sebagai agen perubahan. Di kelasnya, Sarwar bekerja dengan 104 mahasiswa perempuan yang telah membuat komitmen untuk bergabung dan mengikuti kelas bahasa Inggrisnya. Selain itu, mereka juga memiliki akses yang sedikit dan bahkan tidak ada sama sekali dengan bahasa Inggris di luar kelas. Dalam hal ini, mahasiswa sebagai klien di kelas Sarwar.

\section{Adopsi (Adopt)}

Markee (2001) mendefinisikan adopsi sebagai "individu atau institusi yang terlibat dalam proses pengambilan keputusan" (hal. 119). Menurut Rogers (1983, seperti dikutip dalam Markee (2001 hal 119), ada lima langkah dalam proses pengambilan keputusan. Namun, tampaknya langkah ini tidak sesuai 
dengan pekerjaan Sarwar saat ia bekerja sendiri. Jadi, dia membuat keputusan dan mengimplementasikan inovasi sendiri.

\section{Apa (What)}

Sarwar (2001, hal 127) telah mengubah pendapat yang umum bahwa belajar adalah nominal dan tidak mungkin bagi para mahasiswa untuk bekerja dalam kelompok / berpasangan. Selain itu, ia membawa konsep individualisasi dan dilaksanakan dalam kelas besar di Fakultas Humaniora. Sistem pendidikan dalam pekerjaan Sarwar tidak ditentukan. Kelas yang dilakukan oleh Sarwar adalah kelas non sks.

\section{Dimana(Where)}

Cooper (1989, seperti dikutip dalam Markee, 2001, hal 121) menempatkan inovasi pada sosial budaya bukan lokasi geografis. Markee (2001) menyatakan bahwa sejarah, politik, ekonomi, administrasi, kelembagaan dan pelaksanaan sosiolinguistik mempengaruhi inovasi (Markee, 1986a; 1986b seperti dikutip dalam Markee, 2001, hal 121). Pada faktor ekonomi, para mahasiswa pada penelitian Sarwar berasal dari kelompok kelas menengah di mana mereka telah belajar bahasa Inggris selama 7 tahun. Pada faktor sosiolinguistik, mereka berbicara bahasa Urdu sebagai bahasa pertama mereka dan bahasa Inggris dianggap sebagai bahasa asing. Secara administratif, kelas ini bersifat terbuka (suka rela) non sks, dan diajarkan selama dua jam, tiga kali seminggu. Faktor lain tidak ditentukan.

\section{Kapan (When)}

Sarwar mengajar Bahasa Inggris di kelas penelitiannya selama 50 jam sampai akhir program. Namun, tidak jelas apakah ia menindaklanjuti program tersebut setelah menyelesaikan programnya. Dia hanya memberi kuisioner di awal dan di akhir kelas saja.. Sepertinya Sarwar adalah inovator satu-satunya dalam inovasi ELT di kelasnya.

\section{Mengapa(Why)}

Seperti yang sudah ditunjukkan Sarwar dalam proyeknya, dia tidak menyebutkan keuntungan dari inovasinya. Dalam proyek ini, mahasiswa di kelasnya mendapat manfaat dari proyek Sarwar. Selama kelas berlangsung, para mahasiswa bertanggung jawab pada pembelajaran mereka sendiri yang akan membantu keberhasilan studi mereka. Dalam hal kompatibilitas, tidak diketahui apakah sudah ada orang yang menggunakan inovasi ini sebelum Sarwar. Namun, cukup sulit untuk menggunakaan inovasi ini di kelas karena pengajaran tradisional cenderung memiliki pengajaran langsung dan 
membuat siswa tergantung. Dalam konteks pendidikan Pakistan, proses ini tidak mudah. Secara umum, proyek Sarwar mudah dimengerti, namun pengajar perlu waktu untuk menerapkannya di dalam kelas.

\section{Bagaimana(How)}

Dalam melaksanakan proyeknya, Sarwar mengunakan tiga kerangka kerja, yaitu penelitian(research), pengembangan (development) dan difusi (diffusion) atau disingkat RD \& D, pemecahan masalah dan interaksi sosial. Pertama, pada model RD \& D, pekerjaan Sarwar didasarkan pada penelitian akademis. Kedua, dalam memecahkan masalah, diasumsikan bahwa mahasiswa mampu mendiagnosa masalah mereka dan mengetahui bagaimana mengatasinya. Terakhir, dapat dikatakan bahwa proyek ini telah memberikan kesempatan kepada mahasiswa untuk memiliki hubungan sosial di antara teman-teman mereka ketika mereka melakukan tugas-tugas yang diberikan oleh Sarwar.

\section{Inovasi penulis sendiri}

Penulis seorang pengajar bahasa Inggris ESP (English for Specific Purposes), yaitu bahasa Inggris untuk masing-masing cabang ilmu di Universitas Tanjungpura, Pontianak. Dalam mengajar, penulis membuat tiga inovasi. Pertama, penulis biasanya meminta mahasiswa untuk menulis diari dalam bahasa Inggris tentang kegiatan yang dilakukan setiap hari. Kedua, penulis meminta mahasiwa untuk mengunduh dan mendengarkan berita dalam bahasa Inggris yang ada di VOA, dan/atau BBC. Hal ini bermanfaat untuk untuk melatih pendengaran mereka dalam bahasa Inggris yang dilakukan di luar kelas. Mengadakan lomba bahasa Inggris antar fakultas adalah inovasi yang ketiga.

\section{Siapa (Who)}

Dalam inovasi pertama, penulis sebagai adopter seperti yang diusulkan dan penulis memutuskan diri untuk meminta mahasiswa untuk melakukannya. Pada saat yang sama, penulis juga pelaksana (implementer) dan pemasok (supplier). Seperti yang dijelaskan oleh Markee (2001, hal 119) bahwa "sangat mungkin orang yang sama akan memainkan peran yang berbeda".

Pada inovasi yang kedua, penulis sendiri masih sebagai pelaksana dan pemasok. Klien penulis adalah mahasiswa. Usulan terakhir berjalan dengan baik walaupun proyek tersebut baru dilaksanakan satu kali. Program ini telah didukung oleh Kepala UPT Bahasa sebagai adopter awal. Sebagai adopter, 
pelaksana dan pemasok, kami (pengajar Bahasa Inggris ESP) harus merancang jenis perlombaan yang menarik . Jenis lomba yang sudah terlaksana adalah lomba membaca berita, menulis, dan presentasi dalam bahasa Inggris. Klien kami berasal dari mahasiswa semua fakultas di lingkungan Universitas Tanjungpura.

\section{Adopsi (Adopt)}

Inovasi kedua dan ketiga sejalan dengan langkah-langkah yang dilakukan oleh Fulan (1982) seperti dikutip dalam Markee (2001, hal 119); yaitu inisiasi, implementasi, kelanjutan, dan hasil. Penulis beserta tim pengajar lain mengusulkan program ini kepada kepala UPT Bahasa karena beliau bertanggung jawab untuk setiap program mata kuliah bahasa Inggris di universitas. Setelah dia menyetujui program, kami menerapkan program ini dan melanjutkannya sampai akhir semester. Pada akhir semester, program dievaluasi untuk melihat hasilnya.

\section{Apa (What)}

Proposal pertama bertujuan untuk melatih mahasiswa menulis dalam bahasa Inggris. Secara umum, remaja senang menulis bentuk kegiatan yang dilakukannya setiap hari dalam buku harian. Kegiatan ini sejalan dengan apa yang sudah dilakukan oleh mahasiswa tersebut,

Inovasi yang kedua dan ketiga bertujuan untuk mengubah paradigma bahwa Bahasa Inggris adalah materi yang membosankan dan sulit. Selain itu,dengan mendengarkan berita atau informasi dlaam bahasa Inggris yang didapat dari VOA dan BBC, mahasiswa dapat melatih pendengarannya sambil belajar pengucapan yanga dalam teks tersebut. Inovasi yang ketiga diharapkan mahasiswa dapat melatih kemampuannya dalam berbicara, menulis dan dan membaca. Inovasi yang ketiga baru terlaksana satu kali. Sedangkan inovasi kedua, kurang berjalan dengan baik karena sebagian mahasiswa belum mendownload program yang berbahasa Inggris. Selain itu, ada mahasiswa yang tidak mendownload dan melaksanakan program yang sudah disepakati. Hal ini sejalan dengan pendapat Markee (2001) dimana "semua inovasi adalah bisnis yang berisiko sehingga hampir tiga perempat dari inovasi pendidikan cenderung gagal dari waktu ke waktu" (hal. 119).

\section{Dimana(Where)}

Program pembelajaran ini dilakukan dilakukan di Universitas Tanjungpura, dimana mahasiswa berasal dari berbagai latar belakang etnis. Beberapa 
mahasiswa berasal dari Pontianak, dan beberapa dari berbagai daerah di Kalimantan Barat. Kombinasi ini mempengaruhi proses pengajaran karena mahasiswa yang berasal dari luar Pontianak biasanya mempunyai keterampilan bahasa terbatas dibandingkan dengan mereka yang dari Pontianak. Akibatnya, beberapa mahasiswa berpedapat bahwa inovasi yang diusulkan dianggap sulit.

Mahasiswa yang berasal dari berbagai daerah ini memeiliki kebiasaan yang berbeda sehingga berpengaruh terhadap ekonomi pula. Selain itu, mereka juga memiliki bahasa ibu yang berbeda. Mereka biasanya berbicara bahasa daerah mereka sendiri di luar kelas. Bahasa Indonesia adalah bahasa resmi yang digunakan didalam kelas dan bahasa Inggris dianggap sebagai bahasa internasional. Meskipun semua mahasiswa telah belajar bahasa Inggris selama sedikitnya 6 tahun, mereka masih mengalami kesulitan dalam menggunakan bahasa tersebut. Secara administratif, bahasa Inggris diajarkan sebagai bahasa Inggris untuk Keperluan Khusus (ESP). Selanjutnya, mereka hanya belajar bahasa Inggris sekali seminggu dalam waktu dua semester. Faktor-faktor ini jelas mempengaruhi kinerja mahasiswa 'di dalam maupun di luar kelas.

\section{Kapan dan Mengapa (When and Why)}

Mengadopsi program baru membutuhkan waktu. Menurut Markee (2001, hal 122), beberapa adopter akan menerapkan inovasi relatif cepat, tetapi beberapa akan membutuhkan waktu. Masalah ini juga terjadi kepada kami, pengajar Bahasa Inggris ESP. Dalam usulan pertama dan kedua, kami perlu sedikit waktu untuk mengadopsi. Namun, membutuhkan waktu lebih lama untuk mengimplementasikan proposal ketiga. Dalam hal triabilitas, beberapa pengajar berasumsi bahwa program terakhir cukup sulit dicapai karena memakan waktu. Program-program ini berbeda dari ELT sebelumnya. Di masa lalu, ELT hanya diadakan di kelas di mana mahasiswa diberi tugas dan melakukan tugas di kelas. Namun, di saat ini, banyak pengajar meminta mahasiswa untuk melakukan latihan dari sumber luar, misalnya mengunduh program yang ada di internet. Program baru ini memberikan manfaat bagi mahasiswa terutama mereka yang lebih menyukai kegiatan di luar daripada tugas di kelas.

\section{Bagaimana(How)}

Program ini memberikan banyak kegiatan di mana mahasiswa mampu menganalisis dan memecahkan masalah mereka sendiri. Misalnya, ketika 
mereka tahu bahwa mereka membutuhkan latihan untuk skill listening, mereka bisa mengunduh program yang ada di internet seperti VOA dan BBC. Selain itu, mereka juga bisa berpartisipasi dalam kegiatan lomba bahasa Inggris yang diadakan oleh UPT Bahasa di mana mereka bisa mengasah kemampuan mereka dengan mahasiswa di luar jurusan mereka.

\section{Perbandingan}

Dalam beberapa situasi, inovasi dan kerja Sarwar terlihat mirip. Kami berdua memiliki kelas yang besar, dengan menggunakan media di luar kelas, misalnya mendengarkan berita. Meskipun klien Sarwar tidak terlibat dalam mendengarkan berita atau informasi di internet, klien dari kelas penulis dan kelas Sarwar sudah melakukan beberapa tugas dalam setiap topik di perlombaan bahasa Inggris.

Karena kami berdua memiliki banyak mahasiswa dalam satu kelas, kami membiarkan mahasiswa untuk mengatur waktu mereka dalam melakukan beberapa tugas luar baik dengan teman-teman mereka atau dengan mereka sendiri. Kami mencoba untuk meminta siswa untuk bertanggung jawab atas apa yang mereka lakukan. Dengan konsisi seperti ini, agak sulit bagi kami untuk memantau pekerjaan mahasiswa apakah mereka melakukan tugas luar atau tidak. Selanjutnya, proyek Sarwar dan penulis belum menunjukkan prestasi mahasiswa dengan jelas karena Sarwar hanya menggunakan kuisioner di awal dan di akhir kelas. Meskipun penulis melakukan tes di akhir kelas, hasilnya juga tidak menunjukkan sesuatu yang berbeda dengan apa yang sudha dilakukan oleh Sarwar. Hal ini dsebabkan oleh materi yang penulis ajarkan di kelas focus kepada pemahaman wacana.

Hal ini dapat dilihat dengan jelas bahwa individualisasi di kelas penulis dan Sarwar bermanfaat bagi mahasiswa saat mereka belajar mandiri. Selain itu, mereka dapat memecahkan masalah mereka sendiri. Namun, kedua inovasi ini akan kurang efektif bagi mahasiswa yang kurang aktif dalam melakukan aktivitas yang diberikan di luar kelas.

Selain kesamaan kedua inovasi tersebut, ada beberapa perbedaan pada inovasi penulis dan Sarwar. Yang pertama, Sarwar tidak berbagi pekerjaan dengan rekan-rekannya, sedangkan penulis dalam inovasi ketiga, penulis berkerja sama dengan pengajar yang lain. Jadi, Sarwar merancang dan melaksanakan bahan-bahan untuk murid-muridnya tanpa campur tangan dari orang lain. Sebaliknya, penulis harus berdiskusi dengan pengajar lain materi apa yang dipakai di dalam dan di luar kelas. Karena itu, beberapa pengajar lain menjadi resister dalam inovasi yang diusulkan. Ada yang mengaplikasikan materi yang sudah disepakati tetapi ada juga yang tidak melaksanakannya. 
Selanjutnya, meskipun penulis dan Sarwar memiliki kelas besar, Sarwar hanya mengajar satu kelas yang dimana semua mahasiswanya adalah perempuan. Dalam hal karakteristik, tidak ada banyak perbedaan pada mahasiswa tersebut. Namun, penulis mengajar kelas yang berbeda setiap minggu dimana mahasiswa laki-laki dan perempuan berada di dalam kelas yang sama dan latar belakang yang berbeda. Meskipun penulis berbagi pekerjaan dengan beberapa pengajar lain,p sulit bagi kami untuk memeriksa pekerjaan dan kemajuan mahasiswa. Selain itu, mahasiwa di kelas penu Inggris sedangkan pada kelas Sarwar, semua mahasiswanya bersifat suka rela dalam mengikuti kelasnya dan tidak memiliki sks.

\section{Kesimpulan}

Dari persamaan dan perbedaaan dari kedua inovasi ini, dapat disimpulkan bahwa mengajar bahasa di kelas yang besar dapat dicapai jika pengajar dan unsur akademis lain bekerja sama melaksanakan inovasi yang baru. Meskipun inovasi ini bervariasi di setiap negara, difusi inovasi yang bervariasi dapat mengembangkan konsep baru, sehingga individualisasi di dalam kelas besar dapt dilakukan sepanjang bahan ajar cocok dengan mahasiswa dan disiapkan.

Furthermore, individualization in large class can also help the students indentify their problems and overcome them by having group discussion. By doing this, they have the possibilities to benefit from socializing with others.

\section{Referensi}

Markee, N. (2001). The Diffusion of Innovation in Language Teaching. In D.R. Hall A. Hewings (Eds.), Innovation in English Language Teaching: A reader (pp.118-126). London: Routledge.

Sarwar, Z. (2001). Adapting Individualization Techniques for Large Classes.

In D.R. Hall \& A. Hewings (Eds.), Innovation in English Language teaching: A reader (pp.127-136). London: Routledge. 